\title{
PENGARUH KOMPENSASI, MOTIVASI DAN KOMITMEN ORGANISASI TERHADAP KINERJA KARYAWAN PADA BPJS KETENAGAKERJAAN CABANG MEDAN BELAWAN
}

\author{
Putri Kemala Dewi Lubis ${ }^{1 *}$ \\ 1) Program Studi Pendidikan Ekonomi, Fakultas Ekonomi, Universitas Negeri Medan \\ E-mail: putrikemala@unimed.ac.id
}

\begin{abstract}
Abstrak
Penelitian ini bertujuan untuk menganalisis pengaruh kompensasi, motivasi dan komitmen organisasi terhadap kinerja karyawan pada BPJS Ketenagakerjaan Cabang Medan Belawan. Penelitian ini merupakan penelitian asosiatif. Metode yang digunakan dalam pengumpulan data pada penelitian ini berupa kuisioner. Populasi dalam penelitian ini seluruh karyawan yang berada di kantor BPJS Ketenagakerjaan Cabang Medan Belawan. Pengujian hipotesis dalam penelitian ini menggunakan analisis regresi linear berganda. Data yang diperoleh diolah menggunakan SPSS versi 21. Hasil penelitian menunjukkan bahwa secara parsial kompensasi berpengaruh positif dan signifikan terhadap kinerja karyawan. Secara parsial motivasi tidak berpengaruh signifikan terhadap kinerja karyawan. Secara parsial komitmen organisasi berpengaruh terhadap kinerja karyawan. Hasil uji simultan kompensasi, motivasi dan komitmen organisasi berpengaruh terhadap kinerja karyawan
\end{abstract}

Kata Kunci : Kompensasi, Motivasi, Komitmen organisasi, Kinerja Karyawan. 


\section{PENDAHULUAN}

Menciptakan kepuasan kerja karyawan tidak mudah karena kepuasan kerja dapat tercipta jika variabel-variabel yang mempengaruhinya antara lain motivasi kerja, kepemimpinan, dan budaya organisasi dapat dilaksanakan dengan baik dan diterima oleh semua karyawan didalam suatu organisasi. Untuk dapat meraih prestasi sesuai dengan citacita dan harapan perusahaan maka seorang pemimpin dituntut untuk memiliki sebuah kebijakan maupun program yang ditunjukkan kepada para karyawannya agar setiap individu karyawan mendapatkan tingkat kepuasan kerja yang tinggi sehingga dapat berkontibusi secara optimal kepada perusahaan. Kadarisman (2012) mengemukakan bahwa kompensasi adalah penghargaan kepada karyawan secara adil dan layak untuk prestasi kerja dan jasa yang telah dikeluarkan terhadap tujuan organisasi demi tercapainya tujuan organisasi. Imbalan yang diterima pegawai sebagai bentuk kompensasi yang diberikan perusahaan berfungsi sebagai alat untuk memenuhi kebutuhan karyawan, kebutuhan yang terpenuhi akan meningkatkan motivasi kerja karyawan. Faktor lain yang dapat meningkatkan kepuasan kerja dan menumbuhkan semangat kerja karyawan adalah faktor motivasi kerja, apabila karyawan merasa termotivasi dalam menjalankan pekerjaannya maka karyawan tersebut memiliki semangat kerja yang tinggi dan memberikan kontribusi yang besar pada perusahaan. Motivasi kerja adalah sebuah dorongan pada diri karyawan untuk menyelesaikan pekerjaan yang diberikan dalam rangka pencapaian tujuan. Motivasi kerja pegawai tidak selamanya berada dalam kondisi baik, oleh karena itu perlu adanya upaya untuk meningkatkan motivasi kerja disaaat motivasi kerja menurun. Meningkatkan motivasi kerja pegawai bisa dilakukan dengan memperhatikan dan memenuhi kebutuhan pegawai serta menghargai hasil dari pekerjaan mereka. Hasibuan (2007:149) ada dua macam metode untuk meningkatkan motivasi pegawai, yaitu motivasi langsung dengan memenuhi kebutuhan pegawai secara materil dan non materil serta tidak langsung dengan memberikan fasilitasfasilitas untuk menunjang pekerjaan. Dalam hal ini pemimpin juga dituntuk untuk memiliki kebijakan yang bertujuan untuk memberikan kepuasan kerja pada setiap karyawan. Motivasi dan semangat kerja pada diri setiap karyawan sangat memberikan dampak yang positif atau
NIAGAWAN Vol 8 No 3 November 2019 negatif pada hasil pekerjaan karyawan, sehingga apabila seorang karyawan memiliki semangat yang baik maka juga akan memberikan hasil dan kontribusi yang baik bagi perusahaan begitu juga sebaliknya.

Faktor Komitmen organisasi karyawan sangat penting karena adanya komitmen maka karyawan dapat lebih bertanggung jawab terhadap pekerjaannya dibanding dengan karyawan yang tidak mempunyai komitmen bekerja. Menurut Wibowo (2007) komitmen organisasi adalah perasaan, sikap dan perilaku individu mengidentifikasikan dirinya sebagai bagian dari organisasi, terlibat dalam proses kegiatan organisasi dan loyal terhadap organisasi dalam mencapai tujuan. Biasanya karyawan yang memiliki komitmen tinggi, akan bekerja secara optimal dapat mencurahkan perhatian, pikiran, tenaga dan waktunya untuk pekerjaannya, sehingga apa yang dikerjakan sesuai dengan yang diharapakan oleh perusahaan.

\section{TINJAUAN PUSTAKA}

\section{Kinerja Pegawai}

Wirawan (2009, hal 5) mengemukakan bahwa kinerja adalah keluaran yang dihasilkan oleh fungsi-fungsi atau indikator-indikator suatu pekerjaan atau suatu profesi dalam waktu tertentu. Sedangkan menurut Hasibuan (2001, hal 34) Kinerja adalah suatu hasil kerja yang dicapai seseorang dalam melaksanakan tugas-tugas yang dibebankan kepadanya yang didasarkan atas kecakapan pengalaman dan kesungguhan serta waktu. Selanjutnya teori menurut Mangkunegara (2009) kinerja karyawan adalah hasil kerja secara kualitas dan kuantitas yang dicapai oleh seorang karyawan dalam melaksanakan tugasnya sesuai dengan tanggung jawab yang diberikan kepadanya.

\section{Kompensasi}

Saydan (2000) menyatakan kompensasi adalah hasil penjualan tenaga pada terhadap organisasi,namun dalam hal ini terkandung pula pengertian bahwa para karyawan telah memberikan segala kemampuan kerjanya pada organisasi, maka organisasi sudah sewajarnya menghargai jerih payah karyawan itu dengan cara memberikan 
balas jasa atau kompensasi yang setimpa pada mereka. Sedangakan Hasibuan (2003) kompensasi adalah semua pendapatan yang berbentuk uang, barang langsung atau tidak langsung yang diterima karyawan sebagai imbalan atas jasa yang diberikan kepada organisasi. Wibowo (2007) mengemukakan bahwa kompensasi adalah kontra prestasi terhadap penggunaan tenaga atau jasa yang telah diberikan oleh tenaga kerja. Kadarisman (2012) mengemukakan bahwa kompensasi adalah penghargaan kepada karyawan secara adil dan layak untuk prestasi kerja dan jasa yang telah dikeluarkan terhadap tujuan organisasi demi tercapainya tujuan organisasi.

\section{Motivasi}

Wibowo (2007, hal 322) Motivasi merupakan proses psikologi yang membangkitkan dan mengarahkan perilau pada pencapaian tujuan. Rivai (2005, hal 455) menyatakan motivasi adalah serangkaian sikap dan nilai- nilai yang mempengaruhi individu untk mencapai hal yang spesifik sesuai dengan tujuan individu. motivasi adalah pendorong atau penggerakan perilaku kearah yang lebih baik atau kearah pencapaian tujuan.

\section{Komitmen Organisasi}

Komitmen organisasi didefenisikan sebagai keinginan pada sebagian pekerja untuk tetap menjadi anggota organisasi (Colquitt LePine dan Wesson,2011). Menurut Wibowo (2007, hal 429) mengemukakan bahwa komitmen organisasi adalah perasaan, sikap dan perilaku individu mengidentifikasikan dirinya sebagai bagian dari organisasi, terlibat dalam proses kegiatan organisasi dan loyal terhadap organisasi dalam mencapai tujuan.

\section{METODE PENELITIAN}

\section{Populasi dan Sampel}

Populasi dalam penelitian ini adalah karyawan BPJS Ketenagakerjaan Cabang Medan Belawan yang berjumlah 36 orang. Menurut Arfan Ikhsan,dkk (2014 ) sampel
NIAGAWAN Vol 8 No 3 November 2019 adalah bagian dari jumlah dan karakteristik yang dimiliki oleh populasi dan dipilih secara hati-hati dari populasi tersebut. Sampel yang diambil dari populasi harus betul-betul mewakili (Representative). Pemilihan sampel menggunakan total sampling, yaitu jumlah populasi sekaligus menjadi sampel. Pengambilan sampel tersebut hanya dilakukan pada karyawan BPJS Ketenagakerjaan yang bekerja pada semua bagian yang berjumlah 36 orang. Pengujian kuisioner menggunakan uji validitas dan uji reliabilitas

\section{Teknik Analisis Data}

Teknik analisis data yang digunakan dalam penelitian adalah analisis data kuantitatif, yakni menguji dan menganalisis data dengan perhitungan angka-angka dan kemudian menarik kesimpulan dari pengujian tersebut. pengujian regresi dalam penelitian ini menggunakan uji asumsi klasik meliputi uji normalitas, uji multikolinieritas dan uji heteroskedastisitas. Untuk mengetahui pengaruh variabel bebas terhadap variabel terikat digunakan regresi linier berganda dalam penelitian ini persamaan regresi linier berganda sebagai berikut :

$Y=a+\beta \times 1+\beta \times 2+\beta \times 3+\varepsilon$

$\mathrm{Y}=$ Kinerja Pegawai

$\mathrm{X} 1$ = Kompensasi

$\mathrm{X} 2$ = Motivasi

$\mathrm{X} 3$ = Komitmen Organisasi

$\beta=$ Konstanta

$\varepsilon \quad=$ Error

\section{Uji secara Parsial (Uji t)}

Uji statistik $t$ dilakukan menguji apakah variabel bebas (x) secara individu mempunyai hubungan yang signifikan atau tidak terhadap variabel terikat $(\mathrm{y})$. cara pengujian hipotesis uji $\mathrm{t}$ :

H0 : $\rho=0$ (Ada pengaruh variabel bebas dengan variabel terikat)

H1 : $\rho \# 1$ (Tidak ada pengaruh signifikan variabel bebas dengan variabel terikat)

\section{Uji Simultan (Uji F)}

Uji $F$ statistik digunakan untuk menguji keberartian pengaruh dari seluruh variabel bebas yaitu $\left(\begin{array}{llll}\mathrm{X}_{1} & \mathrm{X}_{2} & \mathrm{X}_{3}\end{array}\right)$ berupa variabel kepemimpinan dan variabel motivasi, kompensasi, dan komitmen organisasi terhadap variabel terikat (y) yaitu kinerja karyawan. 
Kriteria penerimaan penolakan hipotesis adalah sebagai berikut :

a. Jika nilai $\mathrm{F}_{\text {hitung }} \geq \mathrm{F}$ tabel tolak Ha sehingga ada pengaruh signifikan antara variabel bebas dengan variabel terikat.

b. Jika nilai $F$ hitung $\leq \mathrm{F}$ tabel terima Ha sehingga tidak ada pengaruh signifikan antara variabel bebas dengan variabel terikat.

\section{Uji Determinasi}

Koefisien determinan merupakan suatu nilai yang menjelaskan variabel bebas dalam mempengaruhi variabel terikatnya dalam suatu persamaan regresi. Nilai koefisien determinan antara 0 dan 1 . Untuk menghitung koefisien determinasi yaitu dengan cara mengkuadratkan koefisien korelasi (Sugiyono, 2011: 185

\section{HASIL DAN PEMBAHASAN}

1. Uji Analisis Regresi Linier Berganda Berdasarkan perhitungan yang dilakukan menggunakan SPSS versi 21 diperoleh persamaan regresi berganda model regresi berganda sebagai berikut :

$$
\mathrm{Y}=33,112+0,368 \mathrm{X} 1+0,913 \mathrm{X} 2-
$$
$0,863 X 3$

Berdasarkan persamaan regresi tersebut dapat dilihat pengaruh kompensasi, motivasi, dan komitmen organisasi terhadap kinerja karyawan jika Kompensasi ditingkatkan 100\% maka kinerja karyawan akan meningkat sebesar 0,368, motivasi ditingkatkan $100 \%$ maka kinerja karyawan akan meningkat 0,913 dan apabila komitmen organisasi menurun $100 \%$ maka kinerja karyawan akan menurun 0,863.

\section{Pengujian Hipotesis}

1. Pengaruh Kompensasi Terhadap Kinerja karyawan

Jika perusahaan memberikan balas jasa ataupun kompensasi yang sesuai kepada karyawannya maka semangat bekerja maupun kinerja karyawan akan meningkat. Jika sebaliknya kompensasi yang diberikan perusahaan tidak sesuai dengan pekerjaan yang dilakukan karyawan, maka kinerja karyawan akan berkurang. Pengaruh kompensasi terhadap kinerja karyawan diperoleh nilai t-hitung 1,003 $<$ t-tabel 2,032. Maka hipotesis nol (HO) diterima, dan menunjukkan bahwa secara parsial ada pengaruh positif dan signifikan antara variabel kompensasi dengan kinerja karyawan.

$$
\text { Kadarisman (2012) pemberian }
$$

kompensasi merupakan salah satu pelaksanaan yang berhubungan dengan semua jenis
NIAGAWAN Vol 8 No 3 November 2019 pemberian penghargaan individual sebagai pertukaran dalam melakukan tugas keorganisasian. Kompensasi merupakan biaya utama atas keahlian atau pekerjaan dan kesetiaan dalam kegiatan keorganisasian. Pemberian kompensasi yang tepat dapat memberikan manfaat kepada karyawan, karena dapat mengahsilkan kinerja karyawan yang tinggi. Pendapat diatas relevan dengan penelitian terdahulu yang dilakukan oleh Eko Galih Sudradjat (2016) yang menyimpulkan dari perhitunga t-tabel sebesar 2,013, dan nilai Sig sebesar 0,004 lebih kecil $5 \%$, sehingga H2 diterima, artinya dengan demikian kompensasi berpengaruh terhadap Kinerja karyawan secara signifikan.

\section{Pengaruh Motivasi Terhadap Kinerja Karyawan}

Motivasi dapat menyebabkan seseorang berperilaku baik, maka motivasi karyawan yang tinggi berbanding lurus dengan kinerja perusahaan. Seorang karyawan yang termotivasi akan energik dan bersemangat dalam mengerjakan tugas-tugas yang diberikan kepadanya. Sebaliknya karyawan yang memiliki motivasi yang rendah akan menampilkan rasa tidak nyaman dan tidak senang terhadap pekerjaannya. Akibatnya kinerja mereka menjadi buruk dan tujuan perusahaan tidak akan tercapai. Tingginya kondisi motivasi kerja pegawai berhubungan dengan kecenderungan pencapaian tingkat kinerja pegawai yang cukup tinggi. Karyawan yang memilik motivasi yang tinggi akan berupaya untuk melakukan semaksimal mungkin tujuan yang ditetapkan oleh perusahaan.

Hasil penelitian menunjukkan bahwa pengaruh motivasi terhadap kinerja karyawan diperoleh nilai t-hitung 2,625 > t-tabel 2,032. Maka hipotesis nol (H0) ditolak dan dapat disimpulkan bahwa motivasi Secara parsial tidak berpengaruh secara signifikan terhadap kinerja karyawan. Penelitian ini tidak sejalan dengan Murty dan Gunasti Hudiwinarsih (2012) yang menyatakan bahwa motivasi berpengaruh terhadap kinerja pegawai secara statistik signifikan.

3. Pengaruh Komitmen Organisasi Terhadap Kinerja Karyawan

Tingkat komitmen baik komitmen perusahaan terhadap karyawan, maupun antara karyawan terhadap perusahaan sangat 
diperlukann karena melalui komitmen-komitmen tersebut akan tercipta iklim kerja yang profesional. Individu yang terpuaskan dengan pekerjaannya cenderung untuk memenuhi komitmen terhadap organisasi, sehingga munculnya loyalitas pegawai terhadap organisasi, yang akhirnya menyebabkan pegawai tersebut memilik rasa ketergantungan dan tanggungjawab pada organisasi. Individu yang memiliki komitmen organisasi rendah cenderung untuk melakukan cara yang dapat mengganggu kinerja organisasi seperti kelambanan dalam bekerja, keluhan dan bahkan mogok kerja. Hasil penelitian menunjukkan pengaruh positif dan signifikan komitmen organisasi terhadap kinerja karyawan diperoleh nilai t-hitung $-2,328<\mathrm{t}$ tabel 2,032. Maka hipotesis nol (H0) diterima dan menunjukkan bahwa secara parsial ada pengaruh signifikan antara variabel Komitmen Organisasi dengan Kinerja Karyawan.

Hasil penelitian ini sesuai dengan penelitian Murty dan Gunasti Hudiningsih (2012), yang menyatakan bahwa Komitmen Organisasi berpengaruh terhadap Kinerja Pegawai secara signifikan.

4. Pengaruh Kompensasi, Motivasi dan Komitmen Organisasi Terhadap Kinerja Karayawan

Hasil penelitian menunjukkan nilai Fhitung lebih besar dari F-tabel 5,742 > 2,92 dengan sig $0,000<$ a 0,05 , menunjukkan $\mathrm{H} 0$ ditolak berarti kompensasi, motivasi dan komitmen organisasi berpengaruh secara signifikan terhadap kinerja karyawan. Dapat disimpulkan bahwa kompensasi motivasi, dan komitmen organisasi berpengaruh secara signifikan dengan kinerja karyawan. Menurut Moeherino (2012) kinerja merupakan gambaran mengenai tingkat pencapaian pelaksanaan suatu program kegiatan atau kebijakan dalam mewujudkan sasran, tujuan, visi dan misi organisasi yang dituangkan melalui perencanaan strategis suatu organisasi.

Dengan menerapkan kompensasi, motivasi dan komitmen organisasi yang baik untuk karyawannya maka otomatis kinerja yang diberikan karyawan untuk perusahaan akan meningkat dan dapat mencapai target kerja yang telah ditetapkan oleh perusahaan, jika sebaliknya kompensasi motivasi dan komitmen organisasi yang tidak wajar yang diberikan perusahaan maka kinerja akan berkurang dan tidak dapat mencapai target kerja yang ditetapkan..

\section{KESIMPULAN DAN SARAN}

Berdasarkan hasil dan pembahasan diatas maka dapat ditarik kesimpulan sebagai berikut: (1). Kompensasi mempunyai pengaruh yang signifikan terhadap kinerja karyawan pada BPJS Ketenagakerjaan Cabang Medan Belawan dapat dilihat hasil uji parsial diperoleh nilai t hitung $1,003<2,032$. (2) Motivasi mempunyai pengaruh yang tidak signifikan terhadap kinerja karyawan pada BPJS Ketenagakerjaan Cabang Medan Belawan dapat dilihat dari hasil uji parsial diperoleh nilai $\mathrm{t}$ hitung 2,625 $>\mathrm{t}$ tabel 2,032 (3) Komitmen Organisasi mempunyai pengaruh yang signifikan terhadap kinerja karyawan pada BPJS Ketenagakerjaan Cabang Medan Belawan dapat dilihat dari uji parsial diperoleh nilai diperoleh nilai $\mathrm{t}$ hitung $-2,328<\mathrm{t}$ tabel 2,032. (4) Hasil uji $F$ nilai signifikan sebesar 0,008 lebih kecil dari 0,05 artinya kompensasi, motivasi dan komiten organisasi berpengaruh signifikan terhadap kinerja karyawan BPJS Ketenagakerjaan Cabang Medan Belawan.

Adapun saran pada penelitian ini adalah: Hasil penelitian ini dapat menjadi referensi bagi BPJS Ketenagakerjaan terkait dengan dengan kompensasi, pimpinan pada kantor BPJS Ketenagakerjaan Cabang Medan Belawan disarankan untuk mempertahankan dan meningkatkan kompensasi yang diberikan perusahaan kepada karyawan, dengan cara memperhatikan kewajaran dan kesesuaian dalam pemberian tunjangan, sepertu tunjangan makan, tunjangan hari raya, dan lain-lain sehingga para karyawan merasa puas dan mempunyai semangat dalam bekerja dan kinerja karyawan akan meningkat. Selanjutnya hasil penelitian ini diharapkan dapat menambah referensi bahan ajar untuk menganalisa prilaku dan motivasi karyawan.

\section{REFERENSI}

Arfan Ikhsan, dkk (2014). Metodeologi Penelitian Bisnis. Medan : Citapustaka Media.

Arfan Ikhsan, dkk (2015). Akuntansi Keperilakuan. Medan : Perdana Publishing

Arfan Ikhsan, dkk (2015). Akuntansi Sektor Publik. Medan : Citapustaka Media.

Azuar Juliandi, dkk (2013). Metode Penelitian kuantitatif. Medan : Umsu Press

Brahmasari dan Agus Suprayetno (2008)."pengaruh motivasi kerja, 
kepemimpinan dan Budaya organisasi

terhadap Kepuasan Kerja karyawan serta Dampaknya pada Kinerja Perusahaan (studi kasus pada PT.PEI Hai International Wiratama Indonesia). Jurnal Manajemen Dan Kewirausahaan, Vol 10 No 2, Hal 124- 135.

Edy Sutrisno (2010). Budaya Organisasi. Jakarta : Kencana Pernada Media Group Hasibuan,Malayu (2012). Manajemen Sumber Daya Manusia. Jakarta : Pt Bumi Aksara.

Kadarisman (2012). Manajemen Kompensasi. Jakarta : Pt Raja Grafindo Persada.

Mahmudi (2010). Manajemen Kinerja Sektor Publik. Sekolah Tinggi Ilmu Manajemen YKPN

Murty Gunasti Hudiwinarsih (2012). Pengaruh Kompensasi, Motivasi, Dan Komitmen Organisasi Terhadap Kinerja Karyawan Bagian Akuntansi (Studi Kasus Pada Perusahaan Manufaktur di Surabaya). The Indonesian Accounting Review, Vol 2 No 2, Hal 215-228.

Mc Donald \& Lawton (1977). Manajemen Sumber Daya Manusia. Terjemahan. Jakarta : PT. Gramedia Pustaka Utama

Nel Arianty, dkk (2016). Manajemen Sumber Daya Manusia. Medan : Perdana Publishing.

Sopiah (2008). Perilaku Organisasi. Andi. Jogyakarta

Sugiyono (2012). Metode Penelitian Bisnis. Bandung : Alfabeta

Wibowo (2014). Manajemen Kinerja . Edisi keempat. Jakarta : Pt Raka Grafindo Persada

Widia Astuti (2014). Akuntansi Manajemen. Mesan : Citapustaka Media Perintis.

Wirawan (2009). Evaluasi Kinerja Sumber Daya Manusia. Jakarta : Salemba Empat 